\title{
Operating Experience of Desalination Unit Coupled to Primary Coolant System of Cirus
}

\author{
R.C. Sharma and Rakesh Ranjan \\ Research Reactor Services Division and Reactor Operations Division, \\ Bhabha Atomic Research Centre, Mumbai, \\ India
}

\section{Introduction}

CIRUS is a $40 \mathrm{MWth}$, heavy water moderated, light water cooled, natural uranium fuelled research reactor located at Mumbai (Bombay), India. Seawater, after removing heat from primary coolant, is released back into sea in an open loop. The reactor had been in operation since 1960 with an average availability factor of about 70\% for about three decades. During early nineties reactor exhibited signs of ageing. Systematic ageing studies were undertaken to identify refurbishment requirements with the aim of extending the life of reactor by 10-15 years. Refurbishment plan was finalized and reactor was shut down for refurbishment during October 1997. During refurbishment, a 30 Ton/day capacity Desalination unit had been integrated with the primary cooling water system of CIRUS towards demonstration of nuclear reactor waste heat utilization for desalination. The desalination unit, developed and designed by BARC, works on low temperature vacuum evaporation process. It was refurbished before shifting it to CIRUS.

A task force evaluated the various available heat sources at CIRUS and worked out the scheme for integrating primary coolant circuit of CIRUS with the desalination unit. The design, procurement, erection, installation and commissioning of the unit was done in-house. During post-refurbishment operation of the reactor, the unit has been operated at its rated capacity and its performance has been satisfactory. The product water has been utilized to meet demineralized water inventory requirement of primary coolant system.

\section{Low Temperature Vacuum Evaporation (LTVE) desalination unit}

Please refer fig 1 . The $30 \mathrm{t} / \mathrm{d}$ LTVE desalination unit is a self-contained unit suitable for installation on a stationary structure or a floating platform. Water jet ejectors are used to create vacuum and pump out concentrated seawater from the evaporator. Scale formation is practically eliminated because of the low boiling temperature and brine density. This unit is eco-friendly, since it does not require chemical pre-treatment of the feed seawater. Apart from the electric energy required for the pump, no other power or fuel is necessary, except for waste heat at around $65^{\circ} \mathrm{C}$ to heat seawater (feed water) to at least $41^{\circ} \mathrm{C}$. 


\subsection{Selection of heat source}

Hot outlet seawater (SW) and primary cooling water (PCW) were considered as heat source for the evaporator - condenser section of the Desalination unit. Minimum temperature and flow of outlet seawater from the reactor to be used as direct source of heat was estimated as $50^{\circ} \mathrm{C}$ and $2500 \mathrm{lpm}$ respectively. Maximum temperature of outlet seawater from CIRUS is $49^{\circ} \mathrm{C}$ at $40 \mathrm{MW}$ operation (at $29^{\circ} \mathrm{C}$ inlet temperature). At lower power levels, the temperature will still be lower. Hence use of outlet seawater as heat source was not feasible. The outlet hot water as feed water itself was found unsuitable due to various operational and radiological considerations.

Since the primary coolant system equipment / piping handles radioactive de-mineralized water, they need to be housed within the reactor building and can't be taken out for direct coupling to the desalination unit installed outside the reactor building from radiological considerations. This necessitated an intermediate circuit as a heat carrier between the primary coolant circuit and the evaporator of the Desalination unit. The need for an intermediate circuit was also necessitated as a barrier between active primary coolant circuit and inactive desalination unit in the event of any leakage from the primary coolant circuit. The intermediate circuit coolant temperature (minimum) and flow, to be effective heat carrier, was envisaged as $53^{\circ} \mathrm{C}$ and $1600 \mathrm{lpm}$ respectively. To achieve this temperature, minimum temperature of primary coolant at the inlet of intermediate circuit heat exchanger was estimated as $58^{\circ} \mathrm{C}$. During normal operation of CIRUS at rated power of $40 \mathrm{MW}$, primary coolant temperature is $80{ }^{\circ} \mathrm{C}$ while at $20 \mathrm{MW}$ operation, it is about $65{ }^{\circ} \mathrm{C}$. Thus adequate margins were available for operation of the unit even when reactor is operated at $50 \%$ of its rated capacity. Adequate space was available in reactor annulus building for installation of intermediate circuit heat exchanger and associated piping and desalination unit just outside the building. Hence primary coolant circuit of CIRUS was found suitable for integration of the desalination unit. Coupling of the primary coolant circuit pipelines with the intermediate circuit heat exchanger was easy as suitable isolation / pipe tapping already existed.

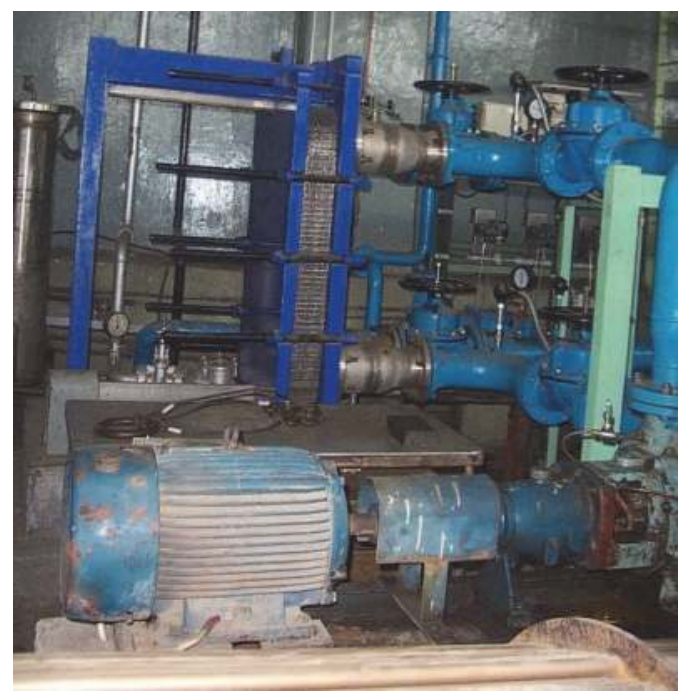

Fig. 1. Plate type H.Ex to transfer heat from primary coolant to intermediate circuit. 


\subsection{Integration of desalination unit with cirus}

A scheme was worked out to transfer heat from primary coolant circuit of reactor to desalination unit through an intermediate (DM water) circuit. An intermediate heat exchanger with associated piping and pump was installed to transport heat to desalination unit. Description of the desalination unit is given below:

About $1 \mathrm{MW}$ of heat energy is transferred from the primary coolant to the desalination unit through an intermediate DM water circuit. For this, $1500 \mathrm{lpm}$ flow is tapped off from the upstream of PCW/ SW heat exchangers. The hot coolant after transferring heat to intermediate circuit in a heat exchanger joins back to primary circuit at the downstream of PCW/ SW heat exchangers.

Intermediate (DM water) circuit works as a heat carrier to the condenser-evaporator unit. Recirculation flow through the circuit is maintained at about $1600 \mathrm{lpm}$. During normal operation, pressure of the intermediate circuit in the heat exchanger remains more than the primary coolant side to prevent ingress of active primary coolant water into the intermediate circuit. About $15 \mathrm{lpm}$ flow is maintained through a de-oxygenator and ion exchanger to control water chemistry.

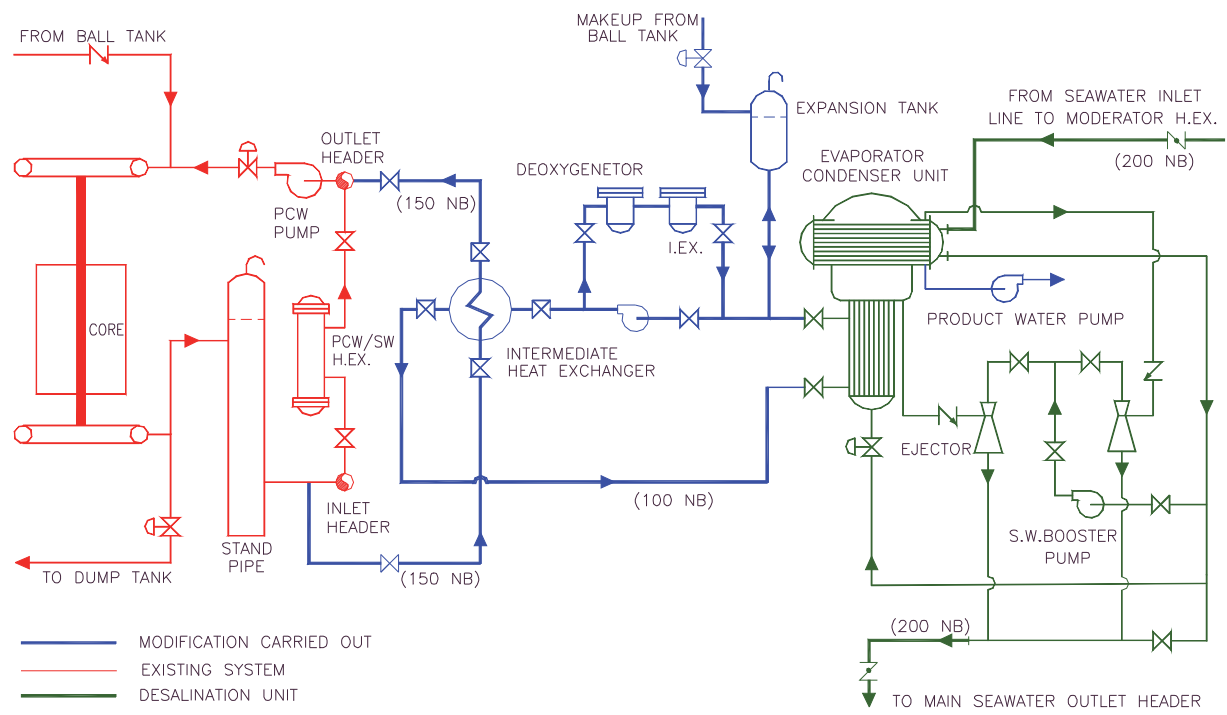

Fig. 2. Schematic of integration of Desalination unit with Cirus

Seawater at $2000 \mathrm{lpm}$ is tapped from main seawater inlet line and is supplied to condenser of the condenser-evaporator unit after passing through a strainer. From the condenser outlet, $65 \mathrm{lpm}$ seawater is supplied as feed water to the evaporator and $1100 \mathrm{lpm}$ through booster pump to the vacuum ejectors as motive force. Normal vacuum created by ejectors is higher than $700 \mathrm{~mm}$ of $\mathrm{Hg}$. The outlet from these units together with the balance flow from condenser outlet joins the main seawater outlet header. The desalination unit is located at about $1.5 \mathrm{~m}$ above ground level to maintain atmospheric pressure at ejector outlets and also to ensure flow of seawater from ejector outlet to main seawater outlet line under gravity. Product water circuit works in an open loop. One conductivity meter is provided on product water pump discharge line. The pump transfers product water from condenser to 
Dump Tank \# 1(underground concrete tank), if specific conductivity of water is below preset value $(20 \mu \mathrm{S} / \mathrm{cm})$. If specific conductivity is high, air operated control valve at pump discharge line diverts product water to storm drain. From Dump Tank \# 1, water is transferred to Dump Tank \# 3 (underground concrete tank) through mixed bed resin cartridge for augmenting the make up requirement of primary cooling water system.

Instrumentation for monitoring various process parameters like flow, temperature, pressure and level has been provided with alarm at appropriate level. All alarms are hooked up to a local panel and a common "off-normal" alarm is provided in control room.

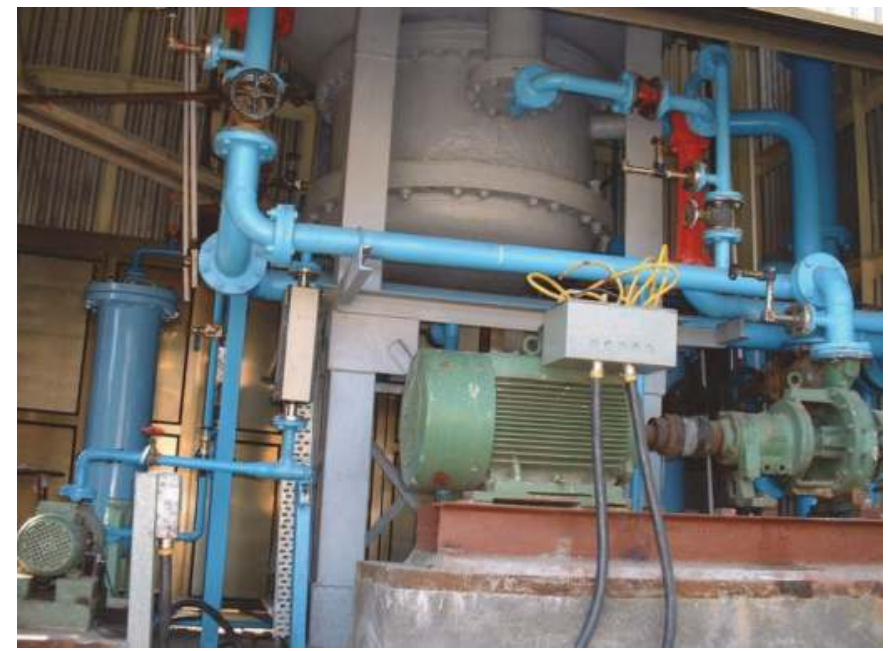

Fig. 3. Evaporator section of Desalination unit and Booster pump

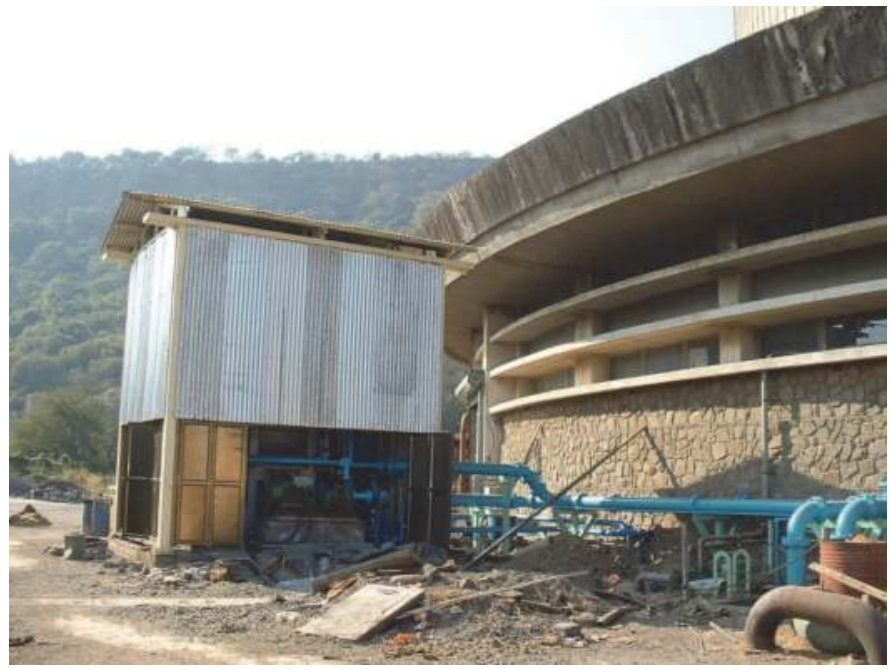

Fig. 4. Desalination unit located outside Cirus annulus area 


\section{Operation of desalination unit}

Operation of desalination unit was commenced after raising reactor power to NP-60\%. Effect of operating the unit on primary coolant circuit of the reactor was assessed and found matching well with design stipulations. All operating parameters of the unit were found as intended. Subsequently reactor power was raised to its rated capacity in steps and all operating parameters were found normal at the corresponding power level. The unit operation at its rated capacity was satisfactory.

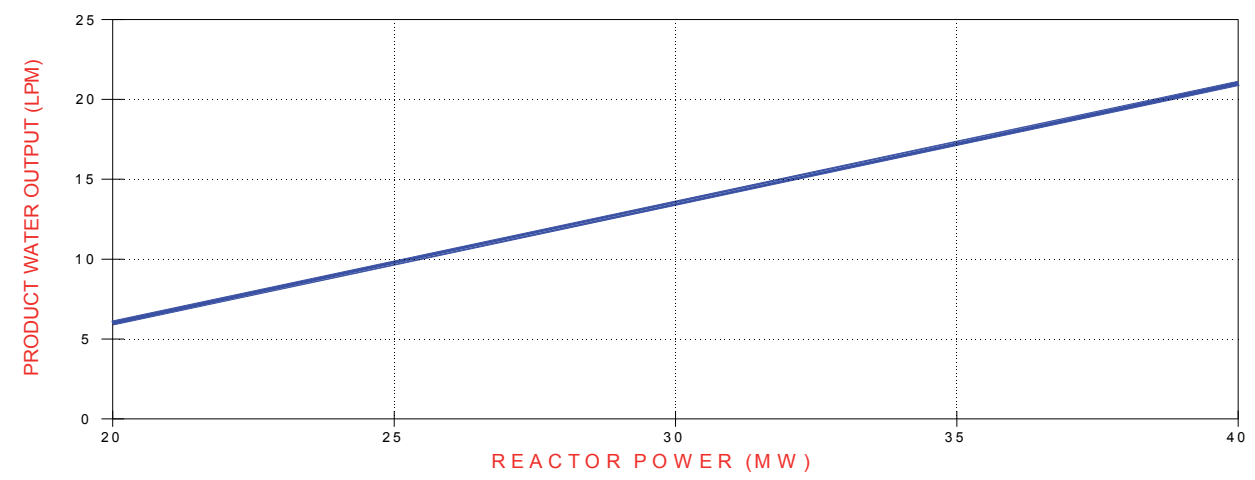

REACTOR POWER VS. PRODUCT WATER OUTPUT

\subsection{Product water quality}

Typical quality of product water generated from desalination unit was as below:

\begin{tabular}{|c|c|c|c|c|c|c|c|c|c|c|c|}
\hline $\mathrm{pH}$ & $\begin{array}{c}\mathrm{K} \\
(\mu \mathrm{S} / \mathrm{cm})\end{array}$ & $\begin{array}{c}\mathrm{TDS} \\
\mathrm{ppm}\end{array}$ & $\begin{array}{c}\mathrm{Na} \\
\mathrm{ppm}\end{array}$ & $\begin{array}{c}\mathrm{K} \\
\mathrm{ppm}\end{array}$ & $\begin{array}{c}\mathrm{Ca} \\
\mathrm{ppm}\end{array}$ & $\begin{array}{c}\mathrm{Mg} \\
\mathrm{ppm}\end{array}$ & $\begin{array}{c}\mathrm{Fe} \\
\mathrm{ppm}\end{array}$ & $\begin{array}{c}\mathrm{Cu} \\
\mathrm{ppm}\end{array}$ & $\begin{array}{c}\mathrm{Ni} \\
\mathrm{ppm}\end{array}$ & $\begin{array}{c}\mathrm{SiO}_{2} \\
\mathrm{ppm}\end{array}$ & $\begin{array}{c}\mathrm{Cl}^{-} \\
\mathrm{ppm}\end{array}$ \\
\hline 5.8 & $15-18$ & 9.8 & 1.4 & $<0.1$ & 0.1 & 0.2 & 0.59 & 0.31 & 0.17 & $<0.2$ & 3.9 \\
\hline
\end{tabular}

Table 1.

To generate de-mineralized water for primary coolant inventory, service water supplied by City Municipal Corporation, is passed through ion exchangers. The specific conductivity of service water varies between $100-160 \mu \mathrm{S} / \mathrm{cm}$ while that of product water generated by desalination unit could be achieved as low as $15 \mu \mathrm{S} / \mathrm{cm}$. Hence use of product water as feed stock for DM water has resulted into reduction in demand for operation of ion exchangers. Consequently consumption of regenerants, generation of liquid waste for regeneration of ion exchangers and Person-Seivert consumption has also come down.

\subsection{Installation of demister}

Towards improving the quality of product water, demister pads (made of knitted wire mesh of layered configuration of SS 316 having wire diameter of $0.3 \mathrm{~mm}, 50 \mathrm{~mm}$ thick and provided with SS 316 support grid at the bottom) were installed in the evaporator section of the unit. With this, product water specific conductivity came down from $10-15 \mu \mathrm{S} / \mathrm{cm}$ to $3-4 \mu \mathrm{S} / \mathrm{cm}$. As pads were not knitted as per the size of evaporator, but fabricated from the 
rectangular pieces available in the market, bypassing of entrainments could not be eliminated completely. Also available pads were of $50 \mathrm{~mm}$ thick only against the designed thickness of $75 \mathrm{~mm}$. Procurement of pads of required thickness is on hand and its knitting at site as per the actual shape will result into achieving the desired quality of DM water of $2 \mu \mathrm{S} / \mathrm{cm}$.
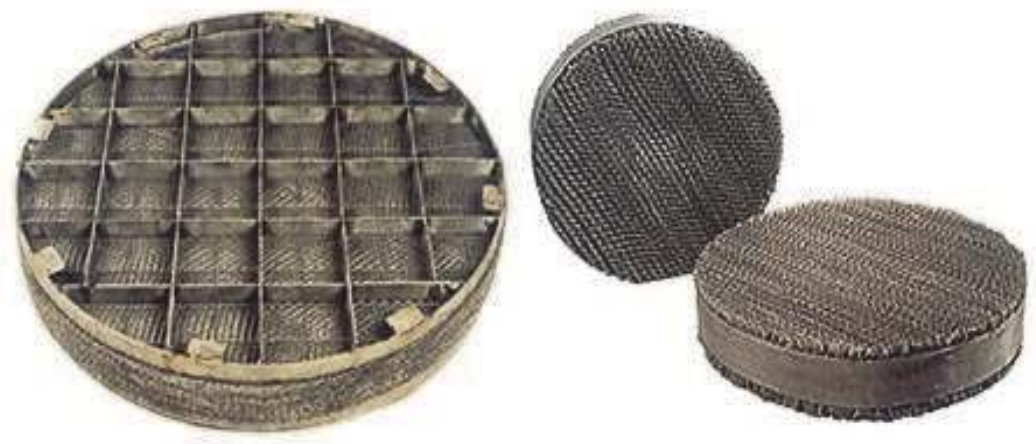

Fig. 5. Demister Pads

With the installation of demister pads, initial start up time of the unit (time for the product water specific conductivity to come down less than $20 \mathrm{uS} / \mathrm{cm}$ ) has come down to less than 1.0 hour from 3-4 hours earlier. It has further resulted into reduction in i) demand for operation of ion exchangers, ii) generation of liquid waste for regeneration of ion exchangers, iii) consumption of regenerants and iv) Person-Seivert consumption.

\section{Experience with the operation of desalination unit}

The successful integration of low temperature vacuum evaporation unit with CIRUS has demonstrated the technology for use of low temperature waste heat for generation of desalinated potable water. The unit has been operating successfully at rated capacity. The operation of the unit for over five years has provided valuable experience related to behavior of the unit during normal as well as off-normal conditions which will serve as feedback for further improvement. Some of the important observations are described below:

- High leakage through gland packing of intermediate circuit pump and product water pump used to be a constant problem during the initial days of the unit operation. Apart from loss of water from system and spillage in area, the pumps used to lose suction resulting into shut down of the unit. Both the pumps have been replaced with the pumps having mechanical seals. The pump availability and hence the unit availability has significantly improved.

- Sea water booster pumps also used to develop frequent leak from gland packing. The pumps used to lose suction resulting into shut down of the unit. Installation of mechanical seal did not help as suspended matter in sea water used to erode the sealing surface of the seals. External cooling with service water has been provided and pump availability has significantly improved.

- Specific conductivity meter of product water was fouling frequently due to water stagnancy as it was located at one dead end of the pipe. The conductivity meter cell has 
been shifted to appropriate location with minor modification in piping lay out such that continuous water flow takes place through its housing.

- Condenser \& Evaporator level - Tiny air bubbles were observed in the product water level gauge of condenser if the level was below $250 \mathrm{~mm}$. To maintain more than 250 $\mathrm{mm}$ level, frequent adjustment of product water flow was needed by throttling product water pump discharge valve. Hence one $1 / 2$ " line with a valve was installed in parallel to product water discharge valve ( $1^{\prime \prime}$ size) for better control of product water flow and condenser water level in desired range $(250-350 \mathrm{~mm})$ could be achieved.

- On a typical occasion when unit was started, specific conductance of product water was not coming down below $1000 \mu \mathrm{S} / \mathrm{cm}$ although all other operating parameters of the unit showed normal values except quick level build up in the condenser. Detailed inspection revealed that a dished shape separator located between evaporator and condenser section which returns back the brine carried over with vapors to the evaporator and hence controls the quality of the product water; had got detached and fallen down. The separator was held in position by a M.S. hanger attached to the condenser. The hanger failed after two years of service due to corrosion and hence the separator fell down over the evaporator. The separator was fixed back in its position with hangers made of SS 316. An additional hanger was also provided and normal operation of the unit was resumed.

- The evaporator-condenser section of desalination unit employs two ejectors. Ejector \#1 is primarily used for creation of vacuum while ejector \#2 sucks high salinity water from the evaporator and discharges it to the common seawater outlet line to avoid scale formation. It also helps in maintaining water level in the evaporator. Frequent failures of these ceramic lined MS ejectors due to erosion-corrosion was solved by replacing them with SS 316 made ejectors. This improved availability of the unit.

- $\quad$ The suction line of product water pump started leaking frequently due to corrosion as the line remains in contact with high salinity water till the required quality of product water is achieved. The MS line was replaced with that of SS 316.

- Installation of demister improved the quality of product water to near DM water quality.

\section{Conclusion}

Integration of desalination unit with CIRUS and its successful operation has demonstrated the utilization of low temperature waste heat of a nuclear reactor in generation of potable water (or near DM water quality) from seawater. The quality of product water is suitable for generation of demineralised water after polishing through ion exchanger. The valuable experience gained in integrating the unit with an old reactor, commissioning, operation at rated capacity and modifications carried out to improve availability; will be of immense help in installation of such units at the places having potential for utilization of low temperature waste heat.

\section{References}

[1] Design manual of Desalination unit at CIRUS

[2] Commissioning of desalination unit integrated with CIRUS: An internal report of Reactor Group, BARC by Rakesh Ranjan, Surinder Kumar and Alok Srivastava. 
[3] Low temperature vacuum evaporation process for seawater desalination using waste heat from PHWRs by Shri P.K. Tiwari, R.K. Verma, B.M. Misra and H.K. Sadhukhan; IAEA -SM -347/34 proceeding of a symposium Taejon, Republic of Korea, 26-30 May, 1997.

[4] Fresh water generation on board a floating platform: Floating nuclear plants for seawater desalination, IAEA TECHDOC -940, IAEA VIENNA, (1997) 65-70.

[5] Introduction to nuclear desalination - IAEA guide book, Technical series 400, Vienna(2000) 


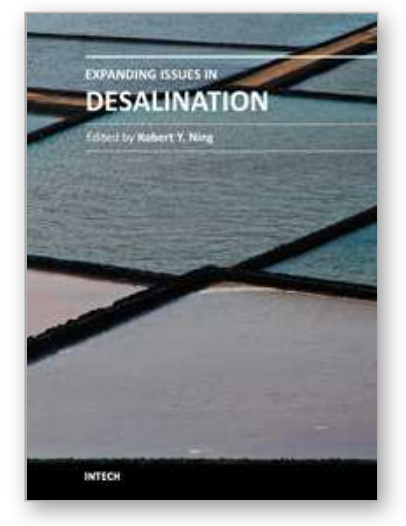

\author{
Expanding Issues in Desalination \\ Edited by Prof. Robert Y. Ning
}

ISBN 978-953-307-624-9

Hard cover, 412 pages

Publisher InTech

Published online 22, September, 2011

Published in print edition September, 2011

For this book, the term â€œdesalinationâ€ is used in the broadest sense of the removal of dissolved, suspended, visible and invisible impurities in seawater, brackish water and wastewater, to make them drinkable, or pure enough for industrial applications like in the processes for the production of steam, power, pharmaceuticals and microelectronics, or simply for discharge back into the environment. This book is a companion volume to â€œDesalination, Trends and Technologiesâ€, INTECH, 2011, expanding on the extension of seawater desalination to brackish and wastewater desalination applications, and associated technical issues. For students and workers in the field of desalination, this book provides a summary of key concepts and keywords with which detailed information may be gathered through internet search engines. Papers and reviews collected in this volume covers the spectrum of topics on the desalination of water, too broad to delve into in depth. The literature citations in these papers serve to fill in gaps in the coverage of this book. Contributions to the knowledge-base of desalination is expected to continue to grow exponentially in the coming years.

\title{
How to reference
}

In order to correctly reference this scholarly work, feel free to copy and paste the following:

R.C. Sharma and Rakesh Ranjan (2011). Operating Experience of Desalination Unit Coupled to Primary Coolant System of Cirus, Expanding Issues in Desalination, Prof. Robert Y. Ning (Ed.), ISBN: 978-953-307624-9, InTech, Available from: http://www.intechopen.com/books/expanding-issues-in-desalination/operatingexperience-of-desalination-unit-coupled-to-primary-coolant-system-of-cirus

\section{INTECH}

open science | open minds

\section{InTech Europe}

University Campus STeP Ri

Slavka Krautzeka 83/A

51000 Rijeka, Croatia

Phone: +385 (51) 770447

Fax: +385 (51) 686166

www.intechopen.com

\section{InTech China}

Unit 405, Office Block, Hotel Equatorial Shanghai

No.65, Yan An Road (West), Shanghai, 200040, China 中国上海市延安西路65号上海国际贵都大饭店办公楼 405 单元

Phone: $+86-21-62489820$

Fax: $+86-21-62489821$ 
(C) 2011 The Author(s). Licensee IntechOpen. This chapter is distributed under the terms of the Creative Commons Attribution-NonCommercialShareAlike-3.0 License, which permits use, distribution and reproduction for non-commercial purposes, provided the original is properly cited and derivative works building on this content are distributed under the same license. 